\title{
Robotic-assisted total hip arthroplasty: a critical appraisal
}

This article was published in the following Dove Press journal:

Robotic Surgery: Research and Reviews

10 December 2014

Number of times this article has been viewed

\section{Jared $M$ Newman \\ Kaitlin M Carroll \\ Michael B Cross}

Department of Orthopaedic Surgery, Hospital for Special Surgery, New York, NY, USA
Correspondence: Michael B Cross Department of Orthopaedic Surgery, Hospital for Special Surgery,

523 East 72nd Street, 7th Floor,

New York, NY 1002I, USA

$\mathrm{Tel}+\mathrm{I} 2127742114$

Fax + I 6467978298

Email crossm@hss.edu
Abstract: Improvements in implant design, surgical technique, and technology have decreased the incidence of complications following a total hip arthroplasty (THA). Robotic-assisted surgery is one technological advance that has improved the reproducibility and accuracy of component placement by customizing the procedure based on the patient's anatomy. However, the learning curve, additional imaging that is required, intraoperative and postoperative complications, and the cost have prevented the widespread use of robotics. The purpose of this systematic review is to analyze two US Food and Drug Administration approved robotic devices (MAKOplasty ${ }^{\mathbb{R}}$ and $\mathrm{ROBODOC}^{\circledR}$ ) that are currently used in THA.

Keywords: orthopedic surgery, robotic devices, navigation technology, component positioning

\section{Introduction}

Total hip arthroplasty (THA) is one of the most successful operations in orthopedic surgery. ${ }^{1}$ In the United States, it is projected that between the years 2005 and 2030 the number of primary THAs will increase by $174 \%$ to 572,000 per year and the number of revision THAs will increase by $137 \%$ to 96,700 per year. ${ }^{2}$ Recent research and product development in THA has been directed at improving clinical outcomes and the survivorship of the prosthesis. A common cause of failure leading to revision after THA is recurrent instability. ${ }^{1}$ Related to instability, another major cause of poor outcomes after THA is impingement, which can lead to implant dislocation, increased rate of material wear, implant loosening, and pain. ${ }^{3}$ In order to reduce the incidence of impingement and instability, product development, including the introduction of navigation and robotics, has focused on ways of successfully implanting the femoral and acetabular components in the "safe" position more frequently.,

Robotic assistance in orthopedic surgery is not a new concept, as outcomes research using robotic surgery has been published for over 20 years. From its inception, robotic surgery was introduced to improve the accuracy of component positioning, with the ultimate goal of increasing the surgeon's reproducibility of performing a THA. ${ }^{6}$ While some may argue that the increased imaging and cost associated with robotics is not justified, proponents of robotics and navigation argue that due to variations in patient anatomy, placing the acetabular and femoral components in a "standard" position without robotic planning may lead to inaccurate component position in some patients with altered anatomy. 
Regardless of the robotic system used, studies have shown that robotic-assisted THAs have better component positioning and potentially better clinical outcomes than patients who had a THA with standard instrumentation. ${ }^{6}$ However, other studies have demonstrated an increased complication rate and cost associated with robotic-assisted THA. ${ }^{7,8}$ Proponents of robotic-assisted THA argue that despite the increased cost and complication rate, better long-term results and more accurate component positioning have been seen with roboticassisted THA. ${ }^{9-17}$

The purpose of this study was to analyze two different US Food and Drug Administration (FDA) approved robotic devices that are currently used in primary THA. We evaluated 1) accuracy of component placement, 2) reproducibility of the procedure, 3) limb alignment 4) clinical outcomes of THA, 5) and complications associated with robotic-assisted THA.

\section{Materials and methods}

A systematic review of the literature was performed using CONSORT guidelines to identify studies that reported outcomes of primary THA using two FDA approved robotic systems, MAKOplasty ${ }^{\circledR}$ and ROBODOC ${ }^{\circledR}$. The electronic medical databases PubMed and EMBASE were searched using key words: "robotic hip arthroplasty", "robotic assisted total hip arthroplasty", and "orthopedic robotic surgery".

Following review of all relevant abstracts, the references in the selected articles were also reviewed to identify any additional studies that were not captured in our initial database search. Inclusion criteria for the studies were: 1) written in the English language, 2) utilized a robotic-assisted device approved by the FDA (MAKOplasty ${ }^{\circledR}$ and ROBODOC $^{\circledR}$ ), and 3 ) the procedure being studied was a primary THA.

In total, 413 studies were initially identified, of which, 15 articles met inclusion criteria for our review (Table 1). ${ }^{7-21}$ Twelve of the 15 articles were clinical studies. In these 12 studies, a total of 682 patients underwent THA using ROBODOC $^{\circledR}$ and 50 patients underwent THA using MAKOplasty ${ }^{\circledR}$. The combined mean follow-up time for all studies was 26.35 months (range, 1-67). ${ }^{7-13,15,17-19,21}$ The remaining three studies were cadaveric studies, where a total of 15 cadavers had components placed with the ROBODOC $^{\circledR}$ and 6 cadavers had components placed using the MAKOplasty ${ }^{\circledR} \cdot{ }^{14,16,20}$

\section{Robotic systems ROBODOC ${ }^{\circledR}$}

The first active robotic-assisted system designed was ROBODOC $^{\circledR}$ (Curexo Technology Corporation, Fremont,
Table I Studies comparing robot-assisted to manual implantation THA (total hip arthroplasty)

\begin{tabular}{|c|c|c|c|}
\hline Author & $\begin{array}{l}\text { Robotic } \\
\text { device }\end{array}$ & $\begin{array}{l}\text { Number of } \\
\text { hips }\end{array}$ & $\begin{array}{l}\text { Mean } \\
\text { follow-up } \\
\text { (months) }\end{array}$ \\
\hline Bargar et al ${ }^{9}$ & ROBODOC ${ }^{\circledR}$ & $\begin{array}{l}\mathrm{n}=127 \text { at } 12 \text { months } \\
\text { Robotics: } 65 \\
\text { Controls: } 62 \\
\mathrm{n}=93 \text { at } 24 \text { months } \\
\text { Robotics: } 48 \\
\text { Controls: } 45\end{array}$ & $12-24$ \\
\hline $\begin{array}{l}\text { Nakamura } \\
\text { et al }{ }^{10}\end{array}$ & ROBODOC ${ }^{\circledR}$ & $\begin{array}{l}\mathrm{n}=146 \\
\text { Robotics: } 75 \\
\text { Controls: } 7 \mid\end{array}$ & $67(60-85)$ \\
\hline $\begin{array}{l}\text { Nishihara } \\
\text { et al" }\end{array}$ & ROBODOC ${ }^{\circledR}$ & $\begin{array}{l}\mathrm{n}=149 \\
\text { Robotics: } 77 \\
\text { Controls: } 72\end{array}$ & $27.9(24-43.2)$ \\
\hline $\begin{array}{l}\text { Hananouchi } \\
\text { et al }{ }^{12}\end{array}$ & ROBODOC ${ }^{\circledR}$ & $\begin{array}{l}\mathrm{n}=58 \\
\text { Robotics: } 31 \\
\text { Controls: } 27\end{array}$ & 24 \\
\hline Honl et $\mathrm{al}^{7}$ & ROBODOC ${ }^{\circledR}$ & $\begin{array}{l}\mathrm{n}=|4| \\
\text { Robotics: } 6 \mid \\
\text { Controls: } 80 \\
\mathrm{n}=\mid 20 \text { at } 24 \text { months } \\
\text { Robotics: } 5 \mid \\
\text { Controls: } 69\end{array}$ & 24 \\
\hline $\begin{array}{l}\text { Domb } \\
\text { et } \mathrm{al}^{13}\end{array}$ & MAKOplasty ${ }^{\circledR}$ & $\begin{array}{l}\mathrm{n}=100 \\
\text { Robotics: } 50 \\
\text { Controls: } 50\end{array}$ & $\mathrm{n} / \mathrm{a}$ \\
\hline $\begin{array}{l}\text { Hagio } \\
\text { et } a^{18}\end{array}$ & ROBODOC ${ }^{\circledR}$ & $\begin{array}{l}\mathrm{n}=75 \\
\text { Robotics: } 50 \\
\text { Controls: } 25\end{array}$ & $\mathrm{n} / \mathrm{a}$ \\
\hline Lim et $\mathrm{al}^{14}$ & $\mathrm{ROBODOC}^{\circledR}$ & $\begin{array}{l}\mathrm{n}=16 \text { cadaveric hips } \\
\text { Robotics: } 8 \\
\text { Controls: } 8\end{array}$ & $\mathrm{n} / \mathrm{a}$ \\
\hline $\begin{array}{l}\text { Nakamura } \\
\text { et } \text { al }^{15}\end{array}$ & ROBODOC $^{\circledR}$ & $\begin{array}{l}\mathrm{n}=\mathrm{I} / 8 \\
\text { Surface registration: } 40 \\
\text { Pin registration: } 78\end{array}$ & $38(26-52)$ \\
\hline $\begin{array}{l}\text { Nawabi } \\
\text { et al }{ }^{16}\end{array}$ & MAKOplasty ${ }^{\circledR}$ & $\begin{array}{l}\mathrm{n}=12 \text { cadaveric hips } \\
\text { Robotics: } 6 \\
\text { Controls: } 6\end{array}$ & $\mathrm{n} / \mathrm{a}$ \\
\hline $\begin{array}{l}\text { Nishihara } \\
\text { et al }{ }^{17}\end{array}$ & ROBODOC $^{\circledR}$ & $\begin{array}{l}\mathrm{n}=75 \\
\text { Robotics: } 75\end{array}$ & $I^{*}$ \\
\hline Nogler et $\mathrm{al}^{19}$ & ROBODOC $^{\circledR}$ & $\mathrm{n}=18$ & 6* \\
\hline $\begin{array}{l}\text { Nogler } \\
\text { et a }{ }^{20}\end{array}$ & ROBODOC $^{\circledR}$ & $\begin{array}{l}\mathrm{n}=14 \text { cadaveric hips } \\
\text { Robotics: } 7 \\
\text { Controls: } 7\end{array}$ & $\mathrm{n} / \mathrm{a}$ \\
\hline Schulz et al ${ }^{8}$ & ROBODOC ${ }^{\circledR}$ & $\mathrm{n}=97$ & $45.6(34.8-63.6)$ \\
\hline Bach et $\mathrm{a}^{21}$ & ROBODOC ${ }^{\circledR}$ & $\begin{array}{l}\mathrm{n}=50 \\
\text { Robotics: } 25 \\
\text { Controls: } 25 \\
\text { Nonoperative } \\
\text { controls: } 40\end{array}$ & $6 *$ \\
\hline
\end{tabular}

Note: *Exact follow-up time, not the mean follow-up. ${ }^{+}$The values are given as mean, with range in parentheses.

Abbreviation: $\mathrm{n} / \mathrm{a}$, not applicable.

CA, USA). Its development began in 1986 and the first human study was conducted from 1992 to $1993 .{ }^{22}$ Prior to surgery, patients undergo a computed tomography (CT) scan to identify 
the patient's normal anatomy. The CT images are transferred to a computer system, ORTHODOC ${ }^{\circledR}$ (Curexo Technology Corporation), which creates 3-dimensional (3-D) images to allow the surgeon to view the femur concurrently in the axial, sagittal, and coronal planes. The surgeon preoperatively uses these computer generated 3-D plans to determine the size of the prosthesis and its position on the femur.

Intraoperatively, position marking pins are inserted into the patient's lower extremity to help guide the robot and anatomic information is transferred to the ROBODOC ${ }^{\circledR}$. The ROBODOC $^{\circledR}$ has a robotic arm with a milling device that prepares the femoral canal and is used during cementless THA for preparation of the femoral component with the goal of decreasing errors in version and sizing. ${ }^{22}$

\section{MAKOplasty ${ }^{\circledR}$}

The MAKOplasty ${ }^{\circledR}$ navigation system (MAKO Surgical Corporation, Ft Lauderdale, FL, USA) is an advanced surgical technique that uses a surgeon-controlled semiactive robotic-assisted Robotic Arm Interactive Orthopaedic System $\left(\mathrm{RIO}^{\circledR}, \mathrm{MAKO}\right.$ Surgical Corporation). Like the ROBODOC ${ }^{\circledR}$, MAKOplasty ${ }^{\circledR}$ requires that patients have a preoperative CT scan for 3-D preoperative planning based on the patient's anatomy. The $\mathrm{RIO}^{\circledR}$ system utilizes haptic feedback, providing proprioceptive information, along with auditory and visual cues during the operation that guide the surgeon. The Femoral Enhanced Workflow (Enhanced) requires a cortical array in the greater trochanter and surface registration of the proximal femur with a probe array. The Enhanced workflow allows for a guided neck resection and broach and stem tracking.

During acetabulum reaming, the robot limits the reaming a surgeon can perform using haptic feedback, preventing the surgeon from reaming too much bone or improper reaming. During component positioning, the robotic navigation system confirms the appropriate acetabular cup version and inclination, femoral stem version, combined offset, and leg length as compared to the initial surgical plan. The MAKOplasty ${ }^{\circledR}$ provides an accurate assessment of reduced hip length and combined offset.

\section{Results}

Component positioning and alignment of the femoral and acetabular components was statistically better with the robotic-assisted THA with increased precision compared to control groups (Table 2). ${ }^{9-17}$ Furthermore, robotic-assisted THA had more reproducible clinical outcomes with significantly less limb length variance. . $^{70,13,14}$

Overall, the robotic-assisted THA had significantly better femoral component fit and fill compared to controls. ${ }^{9-12,14,17}$
Table 2 Component alignment

\begin{tabular}{ll}
\hline Author & Alignment \\
\hline Bargar et al ${ }^{9}$ & $\begin{array}{l}\text { The robotic group had statistically better } \\
\text { alignment and axial seating compared to controls }\end{array}$ \\
Nishihara et al" & $\begin{array}{l}\text { Postoperatively, the robotic group had } \\
\text { significantly better anteroposterior alignment } \\
\text { compared to controls }(P<0.000 I)\end{array}$ \\
Hananouchi et al ${ }^{12}$ & $\begin{array}{l}\text { There was significantly better mean stem } \\
\text { alignment in the robotic group }\left(0.25^{\circ}\right) \text { compared } \\
\text { to controls }\left(0.47^{\circ}\right),(P=0.01)\end{array}$ \\
Domb et al ${ }^{13}$ & $\begin{array}{l}\text { Correct acetabular cup alignment was more likely } \\
\text { to occur in the robotic compared to the control } \\
\text { group }(P=0.00 I)\end{array}$ \\
Lim et al ${ }^{14}$ & $\begin{array}{l}\text { Significantly better anteroposterior alignment } \\
(P=0.046) \text { and vertical seating }(P=0.023) \text { in the } \\
\text { robotic group compared to controls } \\
\text { No significant differences were observed for } \\
\text { anteroposterior and mediolateral alignment or } \\
\text { vertical seating } \\
\text { When comparing the preoperative and }\end{array}$ \\
& $\begin{array}{l}\text { postoperative } C T \text { images: }<I^{\circ} \text { in anteroposterior } \\
\text { and mediolateral alignment }\end{array}$
\end{tabular}

Abbreviation: CT, computed tomography.

Postoperatively the robotic-assisted THA had better lateral and medial fit with significantly better stem fit and fill compared to controls; however, Nogler et $\mathrm{al}^{20}$ found that there was a large amount of motion around the implant in both the robotic-assisted and control groups, therefore, they found no statistical difference (Table 3).

Clinical outcomes were reported in nine studies following robotic-assisted THA compared to control groups

Table 3 Component fit and fill

\begin{tabular}{|c|c|}
\hline Author & Fit and fill \\
\hline Bargar et $\mathrm{al}^{9}$ & $\begin{array}{l}\text { The robotic group had statistically better lateral } \\
\text { and medial fit and fill than the control group; } \\
\text { the robotic group also had a significantly better } \\
\text { proximal medial fit score }\end{array}$ \\
\hline Nakamura et al ${ }^{10}$ & $\begin{array}{l}\text { The robotic group had better stem fit and fill, } \\
\text { which decreased the amount of stress shielding } \\
\text { compared to the control group }\end{array}$ \\
\hline Nishihara et al"' & $\begin{array}{l}\text { Postoperatively, the robotic group had } \\
\text { significantly better mediolateral fill ratio }(P<0.0 \text { I }) \\
\text { and canal fill ratio }(P<0.05)\end{array}$ \\
\hline Hananouchi et al ${ }^{12}$ & $\begin{array}{l}\text { Robotic group had statistically better proximal } \\
\text { medial fit }(P<0.000 \mathrm{I}) \text { and proximal fill }(P=0.04) \\
\text { compared to controls }\end{array}$ \\
\hline Lim et $\mathrm{al}^{14}$ & The robot allows for a better fit \\
\hline Nishihara et al ${ }^{17}$ & $\begin{array}{l}\text { When comparing the preoperative and } \\
\text { postoperative CT images: mean differences in lateral } \\
\text { and medial gaps were }<\mathrm{I} \mathrm{mm} \text { and }<5 \% \text { in canal fill }\end{array}$ \\
\hline Nogler et $\mathrm{al}^{20}$ & $\begin{array}{l}\text { There was a large amount of motion of the } \\
\text { implant when both the robot and manual } \\
\text { methods of implantation were used; no significant } \\
\text { difference between the two }\end{array}$ \\
\hline
\end{tabular}

Abbreviation: CT, computed tomography. 
Table 4 Clinical outcomes of robotic-assisted THA (total hip arthroplasty)

\begin{tabular}{|c|c|}
\hline Author & Clinical outcomes of THA \\
\hline Bargar et $\mathrm{al}^{9}$ & $\begin{array}{l}\text { Modified Harris hip scores in robotics vs controls } \\
\text { at } 12 \text { months ( } 89.4 \text { vs } 86.6) \text { and at } 24 \text { months } \\
\text { ( } 88.5 \text { vs } 91.1 \text { ) were not significantly different. } \\
\text { There was no significant difference in the Short } \\
\text { Form } 36 \text { scores between the two groups }\end{array}$ \\
\hline Nakamura et al ${ }^{10}$ & $\begin{array}{l}\text { Robotic group had significantly better Japanese } \\
\text { Orthopaedic Association scores compared to } \\
\text { the control group }(P=0.0003)\end{array}$ \\
\hline Nishihara et al" & $\begin{array}{l}\text { Robotic group had significantly higher Merle } \\
\text { D'Aubigne hip scores at } 2 \text { years postoperatively } \\
\text { compared with controls }(P<0.05)\end{array}$ \\
\hline Honl et $\mathrm{al}^{7}$ & $\begin{array}{l}\text { The robotics group had significantly higher Harris } \\
\text { hip scores compared to controls up to } 12 \text { months }\end{array}$ \\
\hline Nishihara et a $\left.\right|^{17}$ & $\begin{array}{l}\text { At } 3 \text { months postoperatively no significant } \\
\text { differences were seen in Merle D'Aubigne scores } \\
\text { when compared to preoperative score }\end{array}$ \\
\hline Schulz et $\mathrm{al}^{8}$ & $\begin{array}{l}\text { The Merle D'Aubigne score significantly } \\
\text { improved }(P<0.00 \text { I); } 85 \% \text { of patients reported } \\
\text { they were satisfied; positive Trendelenberg sign } \\
\text { was found in } 17 \text { patients }\end{array}$ \\
\hline Bach et $\mathrm{a}^{21}$ & $\begin{array}{l}\text { No statistical difference in gait between the } \\
\text { robotic and control groups at } 6 \text { months } \\
\text { postoperatively. Trendelenberg sign found in } \\
\text { five patients in robotic group }\end{array}$ \\
\hline
\end{tabular}

(Table 4). ${ }^{7-11,17,21}$ While some studies demonstrated that patients who underwent a robotic-assisted THA had significantly better outcome scores compared to controls, three studies showed no significant differences. ${ }^{9}, 17,21$

Complication rates following robotic assisted THA ranged from $0 \%$ to $55.5 \%$ (Table 3 ), with seven studies reporting no complications. While some complications were directly associated to the robotic-THA such as pains near the site of pin placement, other complications reported were not directly associated with the robotic device.

\section{Discussion}

The purpose of this systematic review was to analyze the literature to determine the clinical outcomes, as well as the complications associated with robotic-assisted primary THAs. Overall, robotic-assisted surgery was found to have more accurate component positioning and better alignment compared to standard instrumentation; however, while some studies reported no complications, others reported complication rates up to $55 \%$.

Several limitations to this study exist that are inherent in all systematic reviews. The individual studies had varied methodology, level of evidence, and duration of follow-up. Most of the studies had small cohorts of patients, with only a few studies reporting clinical outcomes in a large cohort of patients. Further, the biases of the individual studies were inherently transferred to this study.

Based on our review of the literature, our findings confirm the conclusions reached by other recent studies that robotic-assisted surgery is more accurate and has improved reproducibility compared to standard instrumentation for primary THA. Controversy still exists whether robotic assisted surgery has improved clinical outcomes; Honl et $\mathrm{al}^{7}$ reported statistically better Harris hip scores compared to controls; however, Bargar et $\mathrm{al}^{9}$ found no significant difference in Modified Harris hip scores or SF-36 (Short Form 36) scores between the two groups. Further, Bach et $\mathrm{al}^{21}$ did not find any difference in functional outcome in the robotic group.

Alignment of the femoral and acetabular components was shown to be statistically superior in the robotic groups., ${ }^{911-14,16,17}$ Correct component positioning and sizing is important for the success of THA. Lim et $\mathrm{al}^{14}$ reported better anteroposterior femoral component alignment with the ROBODOC ${ }^{\circledR}$ group compared to controls $(P=0.046)$. Nishihara et $\mathrm{al}^{11}$ reported similar results for the anteroposterior alignment $(P<0.0001)$. Nishihara et a $1^{17}$ compared pre- and postoperative CT images and found a mean difference of less than $1^{\circ}$ in both the anteroposterior and mediolateral alignment. Domb et a $1^{13}$ reported results of using the MAKOplasty ${ }^{\circledR}$ and found it was significantly more likely to obtain correct acetabular cup alignment $(P=0.001)$, inclination $(P=0.004)$, and anteversion $(P=0.002)$ compared to controls. The robotic-assisted devices allowed for increased accuracy and precision for the acetabular cup to have the correct orientation and center of rotation. ${ }^{13,16} \mathrm{Leg}$ length variations were significantly less in the robotic group compared to controls. ${ }^{7,10}$ The robotic group also had significantly better precision in alignment and vertical seating than controls. ${ }^{14}$ Thus, the advantages of robotic-assisted surgery include a patient specific preoperative plan based on each patient's anatomy, and improved reproducibility and accuracy in component positioning. In other words, robotic-assisted surgery may help to decrease human error. ${ }^{16}$

While robotic-assisted surgery certainly has its advantages, it also has its disadvantages. In ROBODOC's initial design, two to three pins were placed in the greater trochanter and femoral condyles to serve as position markers. In one study, it was reported that $55.5 \%$ of patients had severe and persistent medial femoral condyle pain at the pin site; however, in other studies the incidence of thigh or knee pin site pain was between $2.6 \%$ and $4 \% .{ }^{10,15,17,19}$ As a result, the system was upgraded to use a surface identification technique, leading to significantly better clinical scores and lower complications related to the pins. ${ }^{15}$ Furthermore, 
the ROBODOC ${ }^{\circledR}$ is limited to only assisting with the femoral component and it does not aid in preparation of the acetabular portion of the THA. Similarly, other complications related to robotic-assisted THA have been reported. ${ }^{7-10,15,18}$ A total of 22 dislocations, ${ }^{7-10,15}$ eight transient nerve injuries, ${ }^{7-9,15}$ and eleven wound infections occurred in the combined cohorts. ${ }^{7,8}$ Honl et $\mathrm{al}^{7}$ reported a significantly higher dislocation rate, revision surgery rate, and rate of nerve injury in patients who had a THA with ROBODOC ${ }^{\circledR}$ compared to the control group. The higher dislocation rate in this study is especially concerning, as the purpose of robotics is to reduce the dislocation rate. Additionally, Schulz et $\mathrm{al}^{8}$ reported similar results with increased complications in patients who had a THA using the ROBODOC ${ }^{\circledR}$ including femoral perforation, damage to the trochanter, and damage to the rim of the acetabulum. Further, patients must be exposed to an increased amount of radiation because of the need for a preoperative CT scan. Also, the operative time is increased (thought to be due to the learning curve) subjecting the patient to more anesthesia and theoretically increasing the risk of infection. ${ }^{9}$ Finally, although not often published in detail, the cost of the robotic systems can be over a million dollars, ${ }^{23}$ thereby preventing worldwide use of robotics in its current form.

\section{Conclusion}

The future of robotic-assisted orthopedic surgery is vast. The concept of using a robot to improve the accuracy of the position of the components is intriguing to most surgeons worldwide; however, the cost, the learning curve involved, and the complications described above may delay its widespread use. Future robotics will likely use imageless navigation, and the robotic consoles will be much smaller. As robotic technology improves over time, it may eventually lead to widespread use to reduce errors in component position during THA.

\section{Disclosure}

The authors report no conflicts of interest.

\section{References}

1. Bozic KJ, Kurtz SM, Lau E, Ong K, Vail TP, Berry DJ. The epidemiology of revision total hip arthroplasty in the United States. J Bone Joint Surg Am. 2009;91(1):128-133.

2. Kurtz S, Ong K, Lau E, Mowat F, Halpern M. Projections of primary and revision hip and knee arthroplasty in the United States from 2005 to 2030. J Bone Joint Surg Am. 2007;89(4):780-785.

3. Malik A, Maheshwari A, Dorr LD. Impingement with total hip replacement. J Bone Joint Surg Am. 2007;89(8):1832-1842.
4. Tarwala R, Dorr LD. Robotic assisted total hip arthroplasty using the MAKO platform. Curr Rev Musculoskelet Med. 2011;4(3):151-156.

5. Dorr LD, Deshmane P. Precision surgery. Orthopedics. 2009;32(9): 659-661.

6. Paul HA, Bargar WL, Mittlestadt B, et al. Development of a surgical robot for cementless total hip arthroplasty. Clin Orthop Relat Res. 1992;285:57-66.

7. Honl M, Dierk O, Gauck C, et al. Comparison of robotic-assisted and manual implantation of a primary total hip replacement: a prospective study. J Bone Joint Surg Am. 2003;85-A(8):1470-1478.

8. Schulz AP, Seide K, Queitsch C, et al. Results of total hip replacement using the Robodoc surgical assistant system: clinical outcome and evaluation of complications for 97 procedures. Int J Med Robot. 2007;3(4):301-306.

9. Bargar WL, Bauer A, Börner M. Primary and revision total hip replacement using the Robodoc system. Clin Orthop Relat Res. 1998;(354):82-91.

10. Nakamura N, Sugano N, Nishii T, Kakimoto A, Miki H. A comparison between robotic-assisted and manual implantation of cementless total hip arthroplasty. Clin Orthop Relat Res. 2010;468(4):1072-1081.

11. Nishihara S, Sugano N, Nishii T, Miki H, Nakamura N, Yoshikawa H. Comparison between hand rasping and robotic milling for stem implantation in cementless total hip arthroplasty. J Arthroplasty. 2006;21(7):957-966.

12. Hananouchi T, Sugano N, Nishii T, et al. Effect of robotic milling on periprosthetic bone remodeling. J Orthop Res. 2007;25(8): 1062-1069.

13. Domb BG, El Bitar YF, Sadik AY, Stake CE, Botser IB. Comparison of robotic-assisted and conventional acetabular cup placement in THA: a matched-pair controlled study. Clin Orthop Relat Res. 2014;472(1): 329-336.

14. Lim SJ, Kim SM, Lim BH, Moon YW, Park YS. Comparison of manual rasping and robotic milling for short metaphyseal-fitting stem implantation in total hip arthroplasty: a cadaveric study. Comput Aided Surg. 2013;18(1-2):33-40.

15. Nakamura N, Sugano N, Nishii T, Miki H, Kakimoto A, Yamamura M. Robot-assisted primary cementless total hip arthroplasty using surface registration techniques: a short-term clinical report. Int J Comput Assist Radiol Surg. 2009;4(2):157-162.

16. Nawabi DH, Conditt MA, Ranaway AS, et al. Haptically guided robotic technology in total hip arthroplasty: a cadaveric investigation. Proc Inst Mech Eng H. 2013;227(3):302-309.

17. Nishihara S, Sugano N, Nishii T, et al. Clinical accuracy evaluation of femoral canal preparation using the ROBODOC system. J Orthop Sci. 2004;9(5):452-461.

18. Hagio K, Sugano N, Takashina M, Nishii T, Yoshikawa H, Ochi T. Effectiveness of the ROBODOC system in preventing intraoperative pulmonary embolism. Acta Orthop Scand. 2003;74(3):264-269.

19. Nogler M, Maurer H, Wimmer C, Gegenhuber C, Bach C, Krismer M. Knee pain caused by a fiducial marker in the medial femoral condyle: a clinical and anatomic study of 20 cases. Acta Orthop Scand. 2001;72(5):477-480.

20. Nogler M, Polikeit A, Wimmer C, Brückner A, Ferguson SJ, Krismer M. Primary stability of a robodoc implanted anatomical stem versus manual implantation. Clin Biomech (Bristol, Avon). 2004;19(2):123-129.

21. Bach CM, Winter P, Nogler M, Göbel G, Wimmer C, Ogon M. No functional impairment after Robodoc total hip arthroplasty: gait analysis in 25 patients. Acta Orthop Scand. 2002;73(4):386-391.

22. Bargar WL. Robots in orthopaedic surgery: past, present, and future. Clin Orthop Relat Res. 2007;(463):31-36.

23. Plaskos C, Koenig JA, Ponder CE. Robotic-assisted knee replacement surgery. In: Gomes P, editor. Medical Robotics: Minimally Invasive Surgery. Philadelphia: Woodhead Publishing; 2012:113-158. 
Robotic Surgery: Research and Reviews

Dovepress

\section{Publish your work in this journal}

Robotic Surgery: Research and Reviews is an international, peer reviewed, open access, online journal publishing original research, commentaries, reports, and reviews on the theory, use and application of robotics in surgical interventions. Articles on the use of supervisory-controlled robotic systems, telesurgical devices, and shared-control systems are

invited. The manuscript management system is completely online and includes a very quick and fair peer review system, which is all easy to use. Visit http://www.dovepress.com/testimonials.php to read real quotes from published authors.

Submit your manuscript here: http://www.dovepress.com/robotic-surgery-research-and-reviews-journal 